\title{
Effect of granular fertilisers produced from industrial and municipal wastes on the crop yield and their content of macroelements
}

\author{
Edward Krzywy $^{1 *}$, Ewa Możdżer ${ }^{1}$, Żenisgul Bakenowa ${ }^{2}$ \\ ${ }^{1}$ West Pomeranian University of Technology, Szczecin, Department of Soil Science, Grassland Management and Environ- \\ mental Chemistry, Stowackiego 17, 71-434 Szczecin, Poland \\ ${ }^{2}$ Kazakh National Agrarian University, Kazakhstan \\ ${ }^{*}$ Corresponding author: e-mail: edward.krzywy@zut.edu.pl
}

\begin{abstract}
Four granular fertilisers were produced from industrial waste products, such as $\mathrm{CaSO}_{4} \cdot 2 \mathrm{H}_{2} \mathrm{O}$ and $\mathrm{FeSO}_{4} \cdot 7 \mathrm{H}_{2} \mathrm{O}$, coniferous and deciduous sawdust mixture and municipal sewage sludge with addition of mineral fertilisers. Based on the content of organic matter, nitrogen, phosphorus and potassium and heavy metals, these granular fertilisers can be included into the group of organic-mineral fertilisers. In order to determine their manurial value, a vegetation experiment was carried out with these granular fertilisers in which spring rape and spring triticale were the test plants. The study results show that granular fertilisers increased significantly the yields of test plants and their content of macroelements. The granular fertilisers containing $\mathrm{FeSO}_{4} \cdot 7 \mathrm{H}_{2} \mathrm{O}$ increased significantly the yields of test plants and the contents of macroelements when compared to those with $\mathrm{CaSO}_{4} \cdot 2 \mathrm{H}_{2} \mathrm{O}$. As affected by the granular fertilisers containing $\mathrm{CaSO}_{4} \cdot 2 \mathrm{H}_{2} \mathrm{O}$, there was more phosphorus, calcium and sulphur in the test plants. The granular fertilisers composed of the waste products mentioned above can be a cheap source of organic matter and nutrients for plants and may reduce possibility of environmental contamination.
\end{abstract}

Keywords: iron(II) sulphate(VI) heptahydrate, calcium sulphate(VI) heptahydrate, municipal and industrial sewage sludge, yields and chemical composition of test plants.

\section{INTRODUCTION}

A reduced production of natural fertilisers, increase in the area of crops being intended for energy purposes, large area (below 50\%) of the arable land with acidic and very acidic soil reaction as well as high prices for raw materials and mineral fertilisers being produced from them, may lead to the imbalance in organic matter and nutrients for cultivated plants. In the long term, soil fertility and yielding potential may be decreased. Moreover, environment protection measures and changes in the range of fertilisers from single-component fertilisers to multi-component ones may induce a decrease in the content of some nutrients for plants in soil. For example, reduction of sulphur emissions to the atmosphere by factory-installed emitters and decrease in the production of fertilisers such as single super-phosphate and ammonium sulphate containing large quantities of sulphur induced its deficit in the soils of Poland ${ }^{1-2}$.

From among all agrotechnical measures, fertilisation determines the size and chemical composition of cultivated plants in 40 to $60 \%$. The chemical composition of cultivated plants is one of the main parameters showing the yield quality. Therefore, fertilisers should be applied in optimum doses and times and appropriate forms to obtain economically justified crop yields of good quality ${ }^{3-4}$.

Considering this situation, the studies have been started to obtain new, cheap and safe sources of organic matter and nutrients for plants. Attention has been paid to the possibility of using some industrial and municipal wastes for fertilisation purposes. Many wastes contain organic matter and nutrients for plants; however, there can be different pollutants in them and their sanitary condition can raise reservations. These wastes in the raw state not always conform to the standards allowing them to be used for fertilisation and land reclamation purposes ${ }^{5}$. Therefore, municipal and industrial wastes should be subject to physical, chemical and microbiological analyses before being intended for using them in soil fertilisation or land reclamation.

The study aimed at elaborating 4 fertiliser blend formulations with municipal sewage sludge, waste products produced at the Chemical Plant S.A. Police (i.e. calcium sulphate(VI) dihydrate and iron(II) sulphate(VI) heptahydrate from the production of multi-compound mineral fertilisers and titanium dioxide, respectively) and a coniferous and deciduous sawdust mixture with a $60 \%$ addition of ammonium phosphate, urea and potassium salt. The manufactured granular fertilisers were tested in a vegetation experiment in order to determine the crop yield of test plants and some of their qualitative traits.

\section{MATERIAL AND METHODS}

In late 2010 to early 2011, 4 fertiliser blend formulations were elaborated and then subjected to the granulation process. For granulation, $2.0 \mathrm{~kg}$ of each fertiliser blends were prepared. The fertiliser blends prepared were left for $24 \mathrm{~h}$ to react. Then, they were dried at $80-90^{\circ} \mathrm{C}$. After drying, their moisture content was $6-10 \%$. The obtained sinters were ground to powdery form. Sodium lignosulphonate, in the amount of $2.0 \%$ in relation to the weight of fertiliser blends, was added to each obtained powdery forms as a granulation-accelerating agent. The granulation of fertiliser blends was carried out at the Chemical Plant Fosfan S.A. in Szczecin. The material composition of respective fertiliser blends, after conversion to dry matter (DM) is presented in Table $1^{6}$.

The physical and chemical properties of granulated fertiliser blends (granular fertilisers) are presented in Table 2. The detailed characteristic of the chemical properties of these granular fertilisers can be found elsewhere ${ }^{6}$. Microbiological examinations carried out by the Municipal Sewage Treatment Plant in Stargard Szczeciński showed that the municipal sewage sludge 
Table 1. Material composition of fertiliser blends being subjected to granulation (after conversion to $\%$ of dry matter) ${ }^{6}$

\begin{tabular}{|c|c|c|c|c|c|c|c|}
\hline \multirow[b]{2}{*}{$\begin{array}{l}\text { Fertiliser blend } \\
\text { No. }\end{array}$} & \multicolumn{7}{|c|}{$\%$ of components in fertiliser blends } \\
\hline & $\begin{array}{l}\text { sewage } \\
\text { sludge }\end{array}$ & $\begin{array}{c}\text { coniferous and } \\
\text { deciduous } \\
\text { sawdust mixture }\end{array}$ & $\mathrm{FeSO}_{4} \cdot 7 \mathrm{H}_{2} \mathrm{O}$ & $\mathrm{CaSO}_{4} \cdot 2 \mathrm{H}_{2} \mathrm{O}$ & $\begin{array}{l}\text { Ammonium } \\
\text { phosphate }\end{array}$ & Urea & $\mathrm{KCl} 60 \%$ \\
\hline 1 & 30 & 20 & 20 & - & 10 & 10 & 10 \\
\hline 2 & 50 & - & 30 & - & - & 10 & 10 \\
\hline 3 & 30 & 20 & - & 20 & 10 & 10 & 10 \\
\hline 4 & 50 & - & - & 30 & - & 10 & 10 \\
\hline
\end{tabular}

Table 2. Physical and chemical properties of granular fertilisers

\begin{tabular}{|c|c|c|c|c|c|c|c|c|}
\hline \multirow{2}{*}{ Chemical element } & \multicolumn{8}{|c|}{ Type of granular fertiliser } \\
\hline & \multirow{2}{*}{\multicolumn{2}{|c|}{$\begin{array}{c}1 \\
5.91\end{array}$}} & \multirow{2}{*}{\multicolumn{2}{|c|}{$\begin{array}{c}2 \\
6.11\end{array}$}} & \multirow{2}{*}{\multicolumn{2}{|c|}{$\begin{array}{c}3 \\
5.88\end{array}$}} & \multicolumn{2}{|c|}{4} \\
\hline \multirow[t]{2}{*}{$\mathrm{pHH}_{2} \mathrm{O}$} & & & & & & & 6. & \\
\hline & $\mathrm{g} \cdot \mathrm{kg}^{-1} \mathrm{~d} \cdot \mathrm{m}$. & $\%$ & $\mathrm{~g} \cdot \mathrm{kg}^{-1} \mathrm{~d} . \mathrm{m}$. & $\%$ & $\mathrm{~g} \cdot \mathrm{kg}^{-1} \mathrm{~d} \cdot \mathrm{m}$ & $\%$ & $\mathrm{~g} \cdot \mathrm{kg}^{-1} \mathrm{~d} \cdot \mathrm{m}$. & $\%$ \\
\hline C org. & 225 & 22.5 & 220 & 22.0 & 224 & 22.4 & 222 & 22.2 \\
\hline \multicolumn{9}{|c|}{ total content } \\
\hline $\mathrm{N}$ & 7.5 & 7.25 & 66.0 & 6.60 & 74.0 & 7.40 & 65.5 & 6.55 \\
\hline $\mathrm{P}$ & 26.0 & 2.60 & 11.0 & 1.00 & 29.0 & 2.80 & 13.6 & 1.36 \\
\hline $\mathrm{K}$ & 50.0 & 5.00 & 50.5 & 5.05 & 50.5 & 5.05 & 51.0 & 5.10 \\
\hline $\mathrm{Ca}$ & 7.53 & 0.75 & 22.2 & 1.22 & 55.0 & 5.50 & 84.2 & 8.42 \\
\hline $\mathrm{Mg}$ & 0.98 & 0.98 & 1.30 & 0.13 & 1.00 & 0.10 & 1.00 & 0.10 \\
\hline$S$ & 27.0 & 2.70 & 41.0 & 4.10 & 35.0 & 3.50 & 52.2 & 5.22 \\
\hline \multicolumn{9}{|c|}{ in $\mathrm{mg} \cdot \mathrm{kg}^{-1} \mathrm{~d} . \mathrm{m}$. } \\
\hline $\mathrm{N}-\mathrm{NH}_{4}$ & \multicolumn{2}{|c|}{488} & \multicolumn{2}{|c|}{387} & \multicolumn{2}{|c|}{490} & \multicolumn{2}{|c|}{390} \\
\hline $\mathrm{P}$ available & \multirow{2}{*}{\multicolumn{2}{|c|}{$\begin{array}{r}225 \\
95\end{array}$}} & \multirow{2}{*}{\multicolumn{2}{|c|}{$\frac{160}{102}$}} & \multicolumn{2}{|c|}{238} & \multicolumn{2}{|c|}{162} \\
\hline $\mathrm{K}$ available & & & & & \multirow{2}{*}{\multicolumn{2}{|c|}{$\begin{array}{l}98 \\
67\end{array}$}} & \multicolumn{2}{|c|}{104} \\
\hline Mg available & \multicolumn{2}{|c|}{66} & \multicolumn{2}{|c|}{68} & & & 68 & \\
\hline \multicolumn{9}{|c|}{ total content } \\
\hline $\mathrm{Cd}$ & \multirow{2}{*}{\multicolumn{2}{|c|}{$\begin{array}{r}0.98 \\
34.9\end{array}$}} & \multicolumn{2}{|c|}{$\begin{array}{r}1.80 \\
565\end{array}$} & \multicolumn{2}{|c|}{0.96} & \multicolumn{2}{|c|}{1.65} \\
\hline $\mathrm{Cu}$ & & & 56 & & \multirow{2}{*}{\multicolumn{2}{|c|}{$\begin{array}{l}34.8 \\
15.9\end{array}$}} & & \\
\hline $\mathrm{Cr}$ & \multicolumn{2}{|c|}{15.8} & \multicolumn{2}{|c|}{25.9} & & & \multicolumn{2}{|c|}{25.8} \\
\hline $\mathrm{Ni}$ & \multicolumn{2}{|c|}{7.30} & \multicolumn{2}{|c|}{11.5} & \multicolumn{2}{|c|}{7.30} & 11 & \\
\hline $\mathrm{Pb}$ & 16 & & 24 & & & & 2 & \\
\hline $\mathrm{Zn}$ & $36 !$ & & 512 & & 36 & & 515 & \\
\hline
\end{tabular}

being taken for manufacturing of these granular fertilisers did not contain any live eggs of gastrointestinal parasites (Ascaris sp., Trichulis sp., Toxsocara sp.) or bacteria of the genus Salmonella and therefore it could have been used for fertilisation purposes.

The pot vegetation experiment was carried out in the plant house of the West Pomeranian University of Technology, Szczecin in 2011. In the study, a soil material with the granulometric composition of heavy loamy sand, being classified into the rye complex of the soil quality class $\mathrm{IV}^{\mathrm{b}}$, was used.

The soil material being used in the study had a slightly acidic reaction ( $\mathrm{pH}$ 6.0). The content of plant-available phosphorus, potassium and magnesium forms was average. It amounted to $60.9,121$ and $42.5 \mathrm{mg} \cdot \mathrm{kg}^{-1}$ D.M., respectively. The $\mathrm{S}-\mathrm{SO}_{3}$ content was low $(10.2 \mathrm{mg})$. The total content of heavy metals in the soil material did not exceed the standards specified in the Regulation of the Minister of Environment ${ }^{7}$. The pot vegetation experiment was carried out with two test plants: spring rape of the cultivar Larissa and spring triticale of the cultivar Milikaro, following the same fertilisation scheme.

The design of this vegetation experiment included two factors. The type of granular fertilisers was the first factor, while their increasing doses ( 3 doses) were the second one. The design of this vegetation experiment included two factors. The type of granular fertilisers was the first factor, while their increasing doses (3 doses) were the second one. Each experimental treatment was carried out in four replications.

The soil material being collected at the Experimental Station of the West Pomeranian University of Technology,
Szczecin was sieved through a $5 \mathrm{~mm}$ mesh to remove impurities (stones, gravel, plant residues). Next, it was transferred to pots, $9 \mathrm{~kg}$ in each. The number of pots corresponded to that of fertilisation objects in four replications. The size of granular fertiliser doses was determined based on their nitrogen content. A single dose corresponded to $0.5 \mathrm{~g} \mathrm{~N} /$ pot, a doubled dose to $1.0 \mathrm{~g} \mathrm{~N} /$ pot, while a tripled dose to $1.5 \mathrm{~g} \mathrm{~N} /$ pot.

The calculated granular fertiliser doses were introduced into the soil material in pots on 15.04.2011 and mixed together to the depth of 5-7 cm. After 5 days, a multicomponent fertiliser Polifoska PK $\left(20 \% \mathrm{P}_{2} \mathrm{O}_{5}\right.$ and $32 \%$ $\mathrm{K}_{2} \mathrm{O}$ ) was introduced into all pots with the soil material at a dose of $0.6 \mathrm{~g} /$ pot. After three days, 20 seeds of spring rape of the cultivar Larissa and 20 kernels of spring triticale of the cultivar Milikaro per each pot were sown. The rape seeds and triticale kernels were covered with a 1-2 cm layer of quartz sand. The pots were placed under a foil roof to maintain a constant humidity of the soil material at a level of $60 \%$ of full water capacity during the study. The soil material and test plants were sprinkled with distilled water. When the test plants reached a height of $10 \mathrm{~cm}$, their selection was performed, leaving 5 plants in each pot. Five weeks after the emergence of spring rape and at the stage of spring triticale shooting, a nitrogen top dressing was applied in the form of foliar aqueous urea solution, $0.276 \mathrm{~g} \mathrm{~N} /$ pot. At the time when the test plants reached their production maturity, they were harvested, their crop yield was determined, and the samples for laboratory analyses were collected. The averaged samples of spring rape seeds and spring triticale grains were made and then subjected to 
chemical analyses in two replications. At the time when the test plants reached their production maturity, they were harvested, their crop yield was determined, and the samples for laboratory analyses were collected. The samples of test plants collected were dried and then ground. The samples from respective replications for a given fertilisation treatment were combined, creating averaged samples. The averaged samples were subjected to chemical analyses, which were repeated twice.

The content of macroelements in both test plants was determined in average samples of each fertilisation object. The nitrogen content was determined with the Kjeldahl method according the Polish standard ${ }^{8}$, the phosphorus content with the colorimetric method according to Barton, while that of sulphur by the nefelometricmethod (Perkin Elmer Lambda EZ 150 spectrometer). The potassium, magnesium and calcium contents were determined with atomic absorption spectrometry, using a Perkin Elmer AAS 300 spectrometer. The stock solution was obtained after the wet mineralisation of the plant material according to the Polish standards ${ }^{\mathbf{9} 10}$.

Results for the crop yields and the macroelement contents in spring rape seeds and spring triticale grains were analysed with two-way analysis of variances in completely randomised design, using a double interaction. Confidence half-intervals were calculated for $\mathrm{p}=0.05$, using the Tukeya test.

\section{RESULTS}

The crop yields of spring rape seeds and spring triticale grains obtained after treatment with the prepared granular fertilisers are presented in Tables 3 and 4 . The granular fertilisers significantly affected an increase in the yields of spring rape seeds and spring triticale grains when compared to the control objects (Tables 3 and 4). The highest yield of spring rape seeds and spring triticale grains was observed after treatment with the granular fertiliser No. 2, composed of municipal sewage sludge (50\%), iron (II) sulphate (VI) heptahydrate (30\%), urea
$(10 \%)$ and potassium salt $(10 \%)$, and next by the granular fertiliser No. 4 in which, instead of $\mathrm{FeSO}_{4} \cdot 7 \mathrm{H}_{2} \mathrm{O}$, $\mathrm{CaSO}_{4} \cdot 2 \mathrm{H}_{2} \mathrm{O}$ was introduced. These results show that $\mathrm{FeSO}_{4} \cdot 7 \mathrm{H}_{2} \mathrm{O}$ was the factor increasing the yield of test plants. This is confirmed by the earlier studies being carried out by many researchers ${ }^{18-29}$.

Clearly lower yields of the test plants were obtained after treatment with the granular fertiliser No. 1 and next by the granular fertiliser No. 3. These granular fertilisers were composed of municipal sewage sludge (30\%), sawdust (20\%), $\mathrm{FeSO}_{4} \cdot 7 \mathrm{H}_{2} \mathrm{O}$ or $\mathrm{CaSO}_{4} \cdot 2 \mathrm{H}_{2} \mathrm{O}$ $(20 \%)$, ammonium phosphate $(10 \%)$, urea $(10 \%)$ and potassium salt $(10 \%)$.

These data show that higher crop yields are obtained with a higher percentage of municipal sewage sludge $(50 \%)$ in the composition of granular fertilisers. The obtained results find their confirmation in the studies by many authors who observed that municipal sewage sludge and composts produced with it affected an increase in the crop yields as well as improved their qualitative traits ${ }^{11-17}$. Significantly higher yields of the test plants were obtained as affected by granular fertilisers with $\mathrm{FeSO}_{4} \cdot 7 \mathrm{H}_{2} \mathrm{O}$ in their composition when compared to calcium sulphate(VI) dihydrate.

The increasing doses of granular fertilisers significantly augmented the yields of test plants. The highest yields of spring rape seeds and spring triticale grains were obtained on a tripled dose of granular fertilisers (Tables 3 and 4). The highest yield of spring rape seeds was observed after treatment with the granular fertiliser No. 2 at a tripled dose. He was higher by $18.8 \%$ when compared to that with the granular fertiliser No. 3 (Table 3). On the other hand, the highest yield of spring triticale grains was recorded in the fertilisation objects with the granular fertilisers Nos. 2 and 4, applied also at a tripled dose; it was higher by $15.1 \%$ when compared to the granular fertiliser No. 3. This is connected with the increased quantities of nutrients being introduced into soil together with the increasing doses of granular fertilisers (Tables 3 and 4).

Table 3. The crop yield of spring rape seeds, obtained after treatment with the granular fertilisers in 2011

\begin{tabular}{|c|c|c|c|c|c|}
\hline \multirow{2}{*}{ Dose size } & \multicolumn{4}{|c|}{ The crop yield, [g/pot] } & \multirow[b]{2}{*}{ Mean } \\
\hline & 1 & 2 & 3 & 4 & \\
\hline Single & 8.20 & 12.9 & 8.8 & 11.4 & 10.3 \\
\hline Doubled & 11.4 & 15.8 & 11.2 & 15.1 & 13.4 \\
\hline Mean & 11.8 & 15.0 & 11.3 & 14.1 & $x$ \\
\hline Control & \multicolumn{4}{|c|}{6.40} & \\
\hline \multicolumn{5}{|c|}{$\begin{aligned} &{ }^{*} \mathrm{LSD}_{0.05} \text { for: } \text { granular fertiliser type }-0.43 \\
& \text { granular fertiliser dose }-0.34 \\
& \text { interaction }-0.68\end{aligned}$} & \\
\hline
\end{tabular}

*LSD = least significant difference.

Table 4. The crop yield of spring triticale grains, obtained as affected by after treatment with the granular fertilisers in 2011

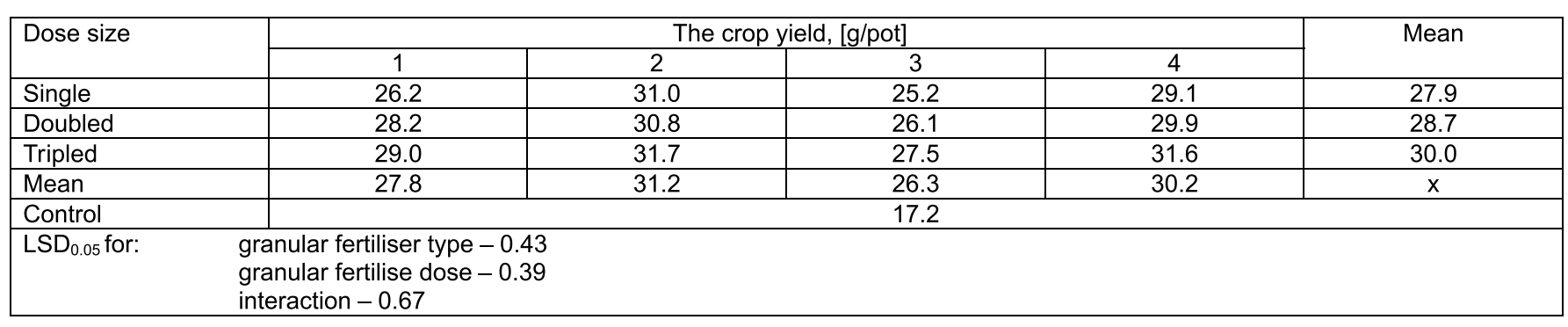


The nitrogen, phosphorus, potassium, calcium, magnesium and sulphur contents in spring rape seeds and spring triticale grains in the control objects were significantly lower when compared to the fertilisation objects where the granular fertilisers were applied (Tables 5, 6, 7 and 8). In spring rape seeds, the nitrogen, phosphorus, potassium, calcium, magnesium and sulphur contents were lower than the average ones given by Panak $^{\mathbf{3 0}}$. In spring triticale grains, the nitrogen, calcium and sulphur contents were higher than the average ones, while the phosphorus, potassium, and magnesium contents were similar to the average ones ${ }^{\mathbf{3 0}}$.

More nitrogen, phosphorus, potassium, magnesium and sulphur was contained by the spring rape seed from the fertilisation objects where the granular fertilisers No. 2 and No. 4, composed of municipal sewage sludge

Table 5. Nitrogen, phosphorus and potassium contents in spring rape seeds obtained after treatment with the granular fertilisers in 2011. Data given in $\mathrm{g} \cdot \mathrm{kg}^{-1}$ D.M.

\begin{tabular}{|c|c|c|c|c|c|c|c|c|c|c|c|c|c|c|c|}
\hline \multirow[t]{2}{*}{ Dose size } & \multicolumn{5}{|c|}{ Nitrogen } & \multicolumn{5}{|c|}{ Phosphorus } & \multicolumn{5}{|c|}{ Potassium } \\
\hline & 1 & 2 & 3 & 4 & mean & 1 & 2 & 3 & 4 & mean & 1 & 2 & 3 & 4 & mean \\
\hline Single & 28.5 & 31.6 & 28.3 & 32.0 & 30.1 & 5.31 & 5.42 & 5.40 & 5.58 & 5.43 & 6.75 & 6.95 & 6.60 & 6.84 & 6.78 \\
\hline Doubled & 31.3 & 33.2 & 30.2 & 33.2 & 32.0 & 5.46 & 5.53 & 5.58 & 5.72 & 5.57 & 6.92 & 7.04 & 6.85 & 7.02 & 6.96 \\
\hline Tripled & 32.5 & 35.0 & 31.8 & 35.2 & 33.6 & 5.35 & 5.50 & 5.83 & 5.95 & 5.66 & 7.20 & 7.32 & 7.18 & 7.30 & 7.25 \\
\hline Mean & 30.8 & 33.3 & 30.1 & 33.5 & 31.9 & 5.37 & 5.48 & 5.60 & 5.75 & 5.55 & 6.96 & 7.10 & 6.87 & 7.05 & 7.00 \\
\hline Control & \multicolumn{5}{|c|}{26.4} & \multicolumn{5}{|c|}{4.98} & \multicolumn{5}{|c|}{5.78} \\
\hline $\begin{array}{l}\mathrm{LSD}_{0.05} \text { for: } \\
\text { granular fertiliser } \\
\text { type }\end{array}$ & \multicolumn{5}{|c|}{1.104} & \multicolumn{5}{|c|}{0.204} & \multicolumn{5}{|c|}{0.185} \\
\hline $\begin{array}{l}\text { granular fertiliser } \\
\text { dose }\end{array}$ & \multirow{2}{*}{\multicolumn{5}{|c|}{0.858}} & \multirow{2}{*}{\multicolumn{5}{|c|}{0.159}} & \multirow{2}{*}{\multicolumn{5}{|c|}{0.144}} \\
\hline interaction & & & & & & & & & & & & & & & \\
\hline
\end{tabular}

Table 6. Calcium, magnesium and sulphur contents in spring rape seeds obtained after treatment with the granular fertilisers in 2011. Data given in $\mathrm{g} \cdot \mathrm{kg}^{-1}$ D.M.

\begin{tabular}{|c|c|c|c|c|c|c|c|c|c|c|c|c|c|c|c|}
\hline \multirow[t]{2}{*}{ Dose size } & \multicolumn{5}{|c|}{ Calcium } & \multicolumn{5}{|c|}{ Magnesium } & \multicolumn{5}{|c|}{ Sulphur } \\
\hline & 1 & 2 & 3 & 4 & mean & 1 & 2 & 3 & 4 & mean & 1 & 2 & 3 & 4 & mean \\
\hline Single & 2.92 & 3.05 & 3.20 & 3.41 & 3.14 & 1.05 & 1.10 & 1.06 & 1.10 & 1.08 & 12.0 & 12.9 & 12.4 & 13.0 & 12.5 \\
\hline Doubled & 3.08 & 3.14 & 3.38 & 3.48 & 3.27 & 1.15 & 1.15 & 1.16 & $1, .21$ & 1.17 & 12.8 & 13.1 & 13.1 & 13.4 & 13.1 \\
\hline Tripled & 3.15 & 3.20 & 3.50 & 3.58 & 3.36 & 1.22 & 1.26 & 1.20 & $1, .25$ & 1.23 & 13.1 & 13.5 & 13.9 & 14.2 & 13.7 \\
\hline Mean & 3.05 & 313 & 3.36 & 3.49 & 3.26 & 1.14 & 1.17 & 1.14 & 1.19 & 1.16 & 12.6 & 13.1 & 13.1 & 13.5 & 13.1 \\
\hline Control & \multicolumn{5}{|c|}{2.22} & \multicolumn{5}{|c|}{0.92} & \multicolumn{5}{|c|}{10.8} \\
\hline $\begin{array}{l}\mathrm{LSD}_{0,05} \text { for: } \\
\text { granular fertiliser } \\
\text { type }\end{array}$ & \multicolumn{5}{|c|}{0.148} & \multicolumn{5}{|c|}{ n.s. } & \multicolumn{5}{|c|}{ n.s. } \\
\hline $\begin{array}{l}\text { granular fertiliser } \\
\text { dose }\end{array}$ & \multicolumn{5}{|c|}{0.115} & \multicolumn{5}{|c|}{0.085} & \multicolumn{5}{|c|}{0.824} \\
\hline interaction & \multicolumn{5}{|c|}{ n.s. } & \multicolumn{5}{|c|}{ n.s. } & \multicolumn{5}{|c|}{ n.s. } \\
\hline
\end{tabular}

Table 7. Nitrogen, phosphorus and potassium contents in spring triticale grains being obtained after treatment with the granular fertilisers in 2011. Data given in $\mathrm{g} \cdot \mathrm{kg}^{-1}$ D.M.

\begin{tabular}{|c|c|c|c|c|c|c|c|c|c|c|c|c|c|c|c|}
\hline \multirow{2}{*}{ Dose size } & \multicolumn{5}{|c|}{ Nitrogen } & \multicolumn{5}{|c|}{ Phosphorus } & \multicolumn{5}{|c|}{ Potassium } \\
\hline & 1 & 2 & 3 & 4 & mean & 1 & 2 & 3 & 4 & mean & 1 & 2 & 3 & 4 & mean \\
\hline Single & 19.0 & 19.5 & 19.1 & 19.3 & 19.2 & 3.15 & 3.21 & 3.21 & 3.30 & 3.22 & 4.75 & 4.95 & 4.75 & 4.88 & 4.83 \\
\hline Doubled & 19.9 & 20.2 & 20.0 & 20.3 & 20.1 & 3.30 & 3.48 & 3.34 & 3.45 & 3.39 & 5.42 & 5.12 & 4.98 & 5.08 & 5.10 \\
\hline Tripled & 20.5 & 21.1 & 20.6 & 21.0 & 20.8 & 3.42 & 3.52 & 3.50 & 3.50 & 3.48 & 5.12 & 5.25 & 5.22 & 5.22 & 5.17 \\
\hline Mean & 19.8 & 20.3 & 19.9 & 20.2 & 20.0 & 3.29 & 3.40 & 3.35 & 3.42 & 3.36 & 5.09 & 5.10 & 4.94 & 5.06 & 5.05 \\
\hline Control & \multicolumn{5}{|c|}{16.2} & \multicolumn{5}{|c|}{2.80} & \multicolumn{5}{|c|}{4.08} \\
\hline $\begin{array}{l}\mathrm{LSD}_{0.05} \text { for: } \\
\text { granular fertiliser } \\
\text { type }\end{array}$ & \multicolumn{5}{|c|}{ n.s. } & \multicolumn{5}{|c|}{ n.s. } & \multicolumn{5}{|c|}{ n.s. } \\
\hline $\begin{array}{l}\text { granular fertiliser } \\
\text { dose }\end{array}$ & \multirow{2}{*}{\multicolumn{5}{|c|}{0.740}} & \multirow{2}{*}{\multicolumn{5}{|c|}{0.124}} & \multicolumn{5}{|c|}{0.254} \\
\hline interaction & & & & & & & & & & & & & n.s & & \\
\hline
\end{tabular}

Table 8. Calcium, magnesium and sulphur contents in spring triticale grains being obtained after treatment with the granular fertilisers in 2011. Data given in $\mathrm{g} \cdot \mathrm{kg}^{-1}$ D.M.

\begin{tabular}{|c|c|c|c|c|c|c|c|c|c|c|c|c|c|c|c|}
\hline \multirow[t]{2}{*}{ Dose size } & \multicolumn{5}{|c|}{ Calcium } & \multicolumn{5}{|c|}{ Magnesium } & \multicolumn{5}{|c|}{ Sulphur } \\
\hline & 1 & 2 & 3 & 4 & mean & 1 & 2 & 3 & 4 & mean & 1 & 2 & 3 & 4 & mean \\
\hline Single & 0.81 & 0.92 & 1.22 & 1.30 & 1.06 & 1.17 & 1.22 & 1.28 & 1.30 & 1.24 & 1.42 & 1.52 & 1.58 & 1.62 & 1.55 \\
\hline Doubled & 0.96 & 1.04 & 1.31 & 1.39 & 1.27 & 1.15 & 1.24 & 1.31 & 1.35 & 1.26 & 1.45 & 1.56 & 1.62 & 1.61 & 1.57 \\
\hline Tripled & 1.08 & 1.08 & 1.38 & 1.42 & 1.24 & 1.20 & 1.26 & 1.34 & 1.40 & 1.30 & 1.48 & 1.61 & 1.76 & 1.76 & 1.63 \\
\hline Mean & 0.95 & 1.01 & 1.30 & 1.37 & 1.15 & 1.17 & 1.24 & 1.31 & 1.35 & 1.26 & 1.45 & 1.56 & 1.67 & 1.68 & 1.59 \\
\hline Control & \multicolumn{5}{|c|}{0.65} & \multicolumn{5}{|c|}{1.12} & \multicolumn{5}{|c|}{1.18} \\
\hline $\begin{array}{l}\mathrm{LSD}_{0.05} \text { for: } \\
\text { granular fertiliser } \\
\text { type }\end{array}$ & \multicolumn{5}{|c|}{0.115} & \multicolumn{5}{|c|}{0.089} & \multicolumn{5}{|c|}{0.038} \\
\hline $\begin{array}{l}\text { granular fertiliser } \\
\text { dose }\end{array}$ & \multicolumn{5}{|c|}{0.090} & \multicolumn{5}{|c|}{ n.s. } & \multicolumn{5}{|c|}{0.030} \\
\hline interaction & \multicolumn{5}{|c|}{ n.s. } & \multicolumn{5}{|c|}{ n.s. } & \multicolumn{5}{|c|}{ n.s. } \\
\hline
\end{tabular}


(50\%), iron(II) sulphate(VI) heptahydrate or calcium sulphate(VI) dihydrate (30\% each), urea $(10 \%)$ potassium salt $(10 \%)$, were applied when compared to the granular fertilisers No. 1 and No. 3, i.e. by about 9.69\%, $2.37 \%, 2.40 \%, 13.9 \%$ and $9.60 \%$, respectively. On the other hand, the highest average content of calcium, by $10.8 \%$, was recorded after treatment of a tripled dose between the granular fertilisers Nos. 1 and 2 and Nos. 3 and 4 (Table 6). The findings suggest a positive effect of granular fertilisers as a result of application of their increasing doses. The highest average increase in the nitrogen and magnesium contents in spring rape seeds was obtained between a single and tripled dose of granular fertilisers, by $11.6 \%$ and $9.60 \%$, respectively.

The calcium, magnesium and sulphur contents in spring triticale grains were the highest in the fertilisation objects being fertilised with the granular fertilisers No. 1 and No. 2, by $36.2 \% 10.8 \%$ and $11.6 \%$, respectively (Table 8 ). The calcium content in the test plants was significantly higher in the fertilisation objects with the granular fertilisers containing $\mathrm{CaSO}_{4} \cdot 2 \mathrm{H}_{2} \mathrm{O}$ when compared to those containing $\mathrm{FeSO}_{4} \cdot 7 \mathrm{H}_{2} \mathrm{O}$. This is connected with higher calcium content in the granular fertilisers with calcium sulphate(VI) dihydrate.

Significantly more sulphur was contained by spring triticale grains in the fertilisation objects where the granular fertilisers with $\mathrm{CaSO}_{4} \cdot 2 \mathrm{H}_{2} \mathrm{O}$ were applied when compared to those containing $\mathrm{FeSO}_{4} \cdot 7 \mathrm{H}_{2} \mathrm{O}$. Although the sulphur content in spring rape seeds in the fertilisation objects with the granular fertilisers containing $\mathrm{CaSO}_{4} \cdot 2 \mathrm{H}_{2} \mathrm{O}$ was higher when compared to those with the granular fertilisers containing $\mathrm{FeSO}_{4} \cdot 7 \mathrm{H}_{2} \mathrm{O}$, these differences were proved to be statistically non-significant.

The increasing doses of granular fertilisers augmented the nitrogen, phosphorus, potassium, calcium, magnesium and sulphur contents in spring rape seeds and spring triticale grains. However, differences in the macroelement contents in the test plants between respective levels of the applied granular fertilisers are not always significant.

The content of nitrogen and potassium in spring rape seeds and that of sulphur in spring triticale grains were significantly higher on a tripled dose of granular fertilisers when compared to doubled doses. The content of phosphorus, calcium, magnesium and sulphur in spring rape seeds and that of nitrogen, phosphorus, potassium, calcium and magnesium in spring triticale grains between the second and the third level of fertilisation with the granular fertilisers produced did not differ significantly. It can be concluded that doubled doses of the granular fertilisers were optimum ones in majority of the fertilisation objects in respect of their effect on development of the macroelement contents in the test plants.

\section{CONCLUSIONS}

The granular fertilisers produced from industrial waste with calcium sulphate(VI) dihydrate, iron(II) sulphate(VI) heptahydrate, coniferous and deciduous sawdust mixture and municipal sewage sludge increased significantly the yield of test plants and their content of macroelements when compared to the control objects.

The crop yields and the content of macroelements in the test plants depended largely on the quantity of nutrients being introduced into the soil material together with granular fertilisers.

Introduction of iron(II) sulphate(VI) heptahydrate into the granular fertilisers increased significantly the yield of spring rape seeds and spring triticale grains when compared to the granular fertilisers containing calcium sulphate(VI) dihydrate.

The granular fertilisers containing $\mathrm{CaSO}_{4} \cdot 2 \mathrm{H}_{2} \mathrm{O}$ increased significantly the $\mathrm{P}, \mathrm{Ca}$ and $\mathrm{S}$ contents in the test plants when compared to those containing $\mathrm{FeSO}_{4} \cdot 7 \mathrm{H}_{2} \mathrm{O}$.

The increasing doses of granular fertilisers augmented the yields of test plants and their content of macroelements. However, the differences are not always significant.

\section{ACKNOWLEDGEMENTS}

Part of this study was conducted within the framework of a research and development project No. N 305155136.

\section{LITERATURE CITED}

1. Morris, R.J. (1988). Sulphur - the fourth major plant nutrient, Proc. of International Symposium on "Sulphur for Korean agriculture”, Seoul, Korea, Proc. 9-16.

2. Kaczor, A. \& Kozłowska, J. (2000). Effect of acidic waste agrosystem. Folia Univ. Agric. Stetin., Agriculturae (204)81, 55-67 [in Polish].

3. Gorlach, E. \& Mazur, T. (2002). Agricultural chemistry. Wyd. PWN Warszawa [in Polish].

4. Krzywy, J., Krzywy, E., Krzywy-Gawrońska, E. \& Rozmarynowska, M. (2007). The effect of sewage sludge composts and potato pulp on uptaking of macroelements by the grain and straw of the spring triticale. Pol. J. Chem. Tech., 9(4), 14-17. DOI: $10.2478 / \mathrm{v} / 10026-007-0081-0$.

5. Regulation of the Minister of Agriculture and Rural Development of 2008. Official Journal of Laws No. 119, item 765 of 2008 [in Polish].

6. Krzywy, E., Możdżer, E. \& Iżewska, A. (2012). Research on the use of industrial wastes for the production of organic and mineral fertilizers and their impact on soil fertility. Sprawozdanie końcowe $\mathrm{z}$ badań przeprowadzonych $\mathrm{w}$ ramach projektu badawczego MNiSW NN 305 155136, ss. 70. [in Polish].

7. Official Journal of Laws No. 165, item 1359 of 2002. [in Polish].

8. Soil quality. Determination of total nitrogen. PN- ISO 11261. [in Polish].

9. Soil quality. Extraction of trace elements in aqua regia. PN-ISO 11466. [in Polish].

10. Soil quality. Determination of elements in soil water extracts royal. Methods flame atomic absorption spectrometry PN-ISO 11047. [in Polish].

11. Krzywy, E., Wołoszyk, Cz., Głowacka, A., \& Krzywy, J. (1998). Studies of $\mathrm{FeSO}_{4} \cdot 7 \mathrm{H}_{2} \mathrm{O}$ action against the amount of fertilizers and crop quality characteristics of some plants. Part I mix reclamation grasses. Folia Univ. Agric. Stetin., Agriculturae (190)72, 159-162 [in Polish].

12. Krzywy, E. \& Jakubowski, W. (2000). Effect of $\mathrm{FeSO}_{4} \cdot 7 \mathrm{H}_{2} \mathrm{O}$ waste phosphogypsum and the sulfur content in the soil, iron, cadmium and nickel. Zesz. Probl. Nauk Rol. 472, 443-448 [in Polish].

13. Pasikowski, K. (2000). Studies on the use of 7 hydrate (VI) iron (II) for use as fertilizers. Praca doktorska. Akad. Rol. Szczec. ss. 86 [in Polish].

14. Krzywy, J. (2001). Measure residual sulfate (VI) iron (II) to yield a mixture of grasses, and on the enzymatic activity of the soil. Uniwersytet Warmińsko-Mazurski w Olsztynie. Praca doktorska, ss. 86 [in Polish]. 
15. Krzywy, E., Krzywy, J. \& Krzywy-Gawrońska, E. (2005). The influence of foliar fertilization by water solution of 7 hydrate sulphate(VI) iron(II) on yielding and chemical composition of cropsi. I. The influence of foliar fertilization with water solution of 7 hydrate sulphate(VI) iron(II) on crops yield quantity. Pol. J. Chem. Tech., 7, 16-18.

16. Krzywy, E., Krzywy, J. \& Krzywy-Gawrońska, E. (2005). The influence of foliar fertilization by water solution of 7 hydrate sulphate(VI) iron(II) on yielding and chemical composition of cropsi. II. The influence of foliar fertilization with water solution of 7 hydrate sulphate(VI) iron(II) on content of nitrogen, phosphorus, potassium, calcium, magnesium, sulphur and iron in plants. Pol. J. Chem. Tech., 7, 19-21.

17. Rozmarynowska, M. (2009). Research on the effects of foliar sulfur and iron by-product of $\mathrm{FeSO}_{4} \cdot 7 \mathrm{H}_{2} \mathrm{O}$ on the quantity and quality characteristics of crop plants. Praca doktorska. Zachodniopomorski Uniwersytet Technologiczny w Szczecinie ss.119 [in Polish].

18. Baran, S. (2004). Sludge in the economy of agri-environmental. Zesz. Prob. Post. Nauk Rol. 499, 15-20 [in Polish].

19. Baran, S. (2005). Resources and organic waste management in Poland. Selected aspects of organic waste and biomass production of willow. Wyd. Uniw. Rzeszow., Rzeszów: 17-40 [in Polish].

20. Kalembasa, S. (2003). Agricultural use of sewage sludge. W:substancje humusowe $w$ glebach $i$ nawozach. Pod red. C. Dąbskiej i S.S. Goneta, Wrocław P.T.S/H.S.:63-74.

21. Krzywy, E., Wołoszyk, C. \& Iżewska, A. (2000). The value of municipal sewage sludge fertilizer. Wyd. PTIE Oddziat Szczeciński: 58 [in Polish].

22. Krzywy, E., Wołoszyk, C. \& Iżewska, A. (2002). Production and agricultural use of sewage sludge compost with the addition of the various components. Wyd. PTIE Oddziat Szczecinski: 39 [in Polish].

23. Łabętowicz, J. \& Stępień, W. (2011). Conditions of recycling waste in the environment. W:Przyrodnicze wykorzystanie odpadów. Wyd. PWRiL Warszawa:11-34 [in Polish].

24. Rosik-Dulewska, C. (2008). Basics of Waste Management. Wyd. PWN Warszawa [in Polish].

25. Siuta, J. \& Wasiak, G. (2001). Rules for the use of sewage sludge on non-industrial purposes (nature). Wyd. PTIE Warszawa nr 3: 13-42 [in Polish].

26. Wołoszyk, C. (2003). Assessment of agrochemical fertilizer composts from municipal sewage sludge and industrial waste. Rozprawa habilitacyjna 217. Wyd. Akad. Rol. Szczec.: 120 [in Polish].

27. Krzywy, E., Krzywy-Gawrońska, E., Krzywy, J. \& Wołoszyk, C. (2007). Impact of composts with participation of municipal sewage sludge on content of available forms of phosphorus for plants and on quantity of spring rape seed yield. Pol. $J$. Chem. Tech. 9(4), 98-101. DOI: 10.2478/v/10026-007-0099-3. 28. Krzywy-Gawrońska, E. (2006). Changes in pH and macronutrient content in composts from potato pulp, straw, sawdust, and municipal sewage sludge during their decomposition. Zesz. Probl. Post. Nauk Rol. 512, 369-379 [in Polish].

29. Krzywy-Gawrońska, E. \& Gutkowska, I. (2007). The content of macro-and micronutrients in perennial ryegrass on the use of compost in potato pulp and municipal sewage sludge. Wyd. IMUZ Raszyn, Czasopismo „Woda, środowisko, obszary wiejskie” 7 z 2a (20), 231-244 [in Polish].

30. Panak, H.,1995. Guide methodical exercise of agricultural chemistry. Wyd. ART. Olsztyn, 240 [in Polish]. 